\title{
The RNA-Binding Protein HuD Binds Acetylcholinesterase mRNA in Neurons and Regulates its Expression after Axotomy
}

\author{
Julie Deschênes-Furry, ${ }^{1}$ Kambiz Mousavi, ${ }^{1}$ Federico Bolognani, ${ }^{2}$ Rachael L. Neve, ${ }^{4}$ Robin J. Parks, ${ }^{5}$ \\ Nora I. Perrone-Bizzozero, ${ }^{3}$ and Bernard J. Jasmin ${ }^{1,5}$ \\ ${ }^{1}$ Department of Cellular and Molecular Medicine and Centre for Neuromuscular Disease, University of Ottawa, Ottawa, Ontario, Canada K1H 8M5, \\ Departments of ${ }^{2}$ Cell Biology and Physiology and ${ }^{3}$ Neurosciences, University of New Mexico School of Medicine, Albuquerque, New Mexico 87131, \\ ${ }^{4}$ Department of Psychiatry, Harvard Medical School, McLean Hospital, Belmont, Massachusetts 02478, and ${ }^{5}$ Molecular Medicine Program, Ottawa Health \\ Research Institute, Ottawa Hospital, General Campus, Ottawa, Ontario, Canada K1H 8L6
}

\begin{abstract}
After axotomy, expression of acetylcholinesterase (AChE) is greatly reduced in the superior cervical ganglion (SCG); however, the molecular events involved in this response remain unknown. Here, we first examined AChE mRNA levels in the brain of transgenic mice that overexpress human HuD. Both in situ hybridization and reverse transcription-PCR demonstrated that AChE transcript levels were increased by more than twofold in the hippocampus of $\mathrm{HuD}$ transgenic mice. Additionally, direct interaction between the HuD transgene product and AChE mRNA was observed. Next, we examined the role of HuD in regulating AChE expression in intact and axotomized rat SCG neurons. After axotomy of the adult rat SCG neurons, AChE transcript levels decreased by 50 and $85 \%$ by the first and fourth day, respectively. In vitro mRNA decay assays indicated that the decrease in AChE mRNA levels resulted from changes in the stability of presynthesized transcripts. A combination of approaches performed using the region that directly encompasses an adenylate and uridylate (AU)-rich element within the $\mathrm{AChE} 3^{\prime}$-untranslated region demonstrated a decrease in RNA-protein complexes in response to axotomy of the SCG and, specifically, a decrease in HuD binding. After axotomy, HuD transcript and protein levels also decreased. Using a herpes simplex virus construct containing the human HuD sequence to infect SCG neurons in vivo, we found that AChE and GAP-43 mRNA levels were maintained in the SCG after axotomy. Together, the results of this study demonstrate that AChE expression in neurons of the rat SCG is regulated via post-transcriptional mechanisms that involve the AU-rich element and HuD.
\end{abstract}

Key words: acetylcholinesterase; HuD; axotomy; mRNA stability; AU-rich element; neurons

\section{Introduction}

Acetylcholinesterase (AChE) is the enzyme responsible for terminating cholinergic neurotransmission in the CNS and peripheral nervous system (PNS), by rapid hydrolysis of acetylcholine (for review, see Massoulie et al., 1993; Legay, 2000; Soreq and Seidman, 2001; Rotundo, 2003). AChE is predominantly expressed in cholinergic tissues (muscle and neurons); however, it is also expressed in some noncholinergic neurons and nonexcitable cells, such as hematopoietic cells (Hammond et al., 1994; Bernard et al., 1995; Brimijoin and Hammond, 1996; Lev-Lehman et al., 1997; Chan et al., 1998). As a result, several noncholinergic roles have been described for AChE including in neurite elongation, cell adhesion, and synaptogenesis (Brimijoin and Hammond, 1996; Koenigsberger et al., 1997; Grifman et al., 1998; Sternfeld et al., 1998; Lev-Lehman et al., 2000; Sharma et al., 2001) (for review, see Soreq and Seidman, 2001). In addition to having these

Received 0ct. 25, 2006; revised Dec. 4, 2006; accepted Dec. 11, 2006.

Work in the Jasmin laboratory was supported by the Canadian Institutes of Health Research, the Muscular Dystrophy Association of America, and the Association Française contre les Myopathies. Work in the PerroneBizzozero laboratory was supported by National Institutes of Health Grant NS30255. We thank Dr. Victor Gisiger for teaching J.D.-F. the surgical techniques (SCG axotomy) used in this study.

Correspondence should be addressed to Dr. Bernard J. Jasmin, Department of Cellular and Molecular Medicine, University of 0ttawa, 451 Smyth Road, 0ttawa, Ontario, Canada K1H 8M5. E-mail: jasmin@uottawa.ca.

DOI:10.1523/JNEUROSCI.4626-06.2007

Copyright $\odot 2007$ Society for Neuroscience $\quad$ 0270-6474/07/270665-11\$15.00/0 nonclassical roles, AChE and its different molecular forms have been implicated in the development of neuronal tumors, in Alzheimer's disease, and in post-traumatic stress disorder (Karpel et al., 1994; Kaufer et al., 1998; Perry et al., 2002). Although AChE is implicated in many different aspects of neuronal development, function, and diseases, the molecular mechanisms involved in regulating its expression are still relatively poorly defined, especially in vivo.

Nevertheless, a small number of distinct studies mostly performed with cultured neuronal cell lines have begun to address the specific roles of transcriptional and post-transcriptional mechanisms in AChE regulation. For instance, during differentiation of cultured neuronal cell lines, initial studies have suggested that increased AChE activity is a downstream consequence of upregulated gene transcription (Greene and Rukenstein, 1981). More recent studies have confirmed that AChE promoter activity is significantly increased during neuronal differentiation (Wan et al., 2000; Siow et al., 2002, 2005; Jiang et al., 2003). Furthermore, transcriptional activation of the AChE gene was reported to occur in response to stress and in aggressive tumor cells (Meshorer et al., 2002, 2004; Perry et al., 2002).

In contrast, an early study performed with pluripotent P19 cells implicated post-transcriptional mechanisms as the principal mechanism involved in AChE mRNA regulation during neuronal differentiation (Coleman and Taylor, 1996). Recently, we re- 
ported that after a transient increase in AChE gene transcription, post-transcriptional events are indeed predominantly responsible for regulating AChE mRNA levels during neuronal differentiation. Specifically, we demonstrated that the RNA-binding protein $\mathrm{HuD}$ [name based on the initials of the patient in which the onconeural antibodies were discovered (for review, see Deschênes-Furry et al., 2006)], a neuronal member of the $\mathrm{Hu}$ family, through binding with the AChE $3^{\prime}$-untranslated region (UTR), could increase AChE mRNA levels via its stabilizing activity (Deschênes-Furry et al., 2003). It remains to be determined, however, whether similar regulatory mechanisms are acting in vivo to mediate $\mathrm{AChE}$ expression in neurons. To this end, we initiated a series of experiments aimed at characterizing the posttranscriptional mechanisms regulating AChE expression in vivo. Specifically, we have examined the interaction of $\mathrm{HuD}$ with AChE mRNA in neurons of the CNS and the importance of this interaction in regulating AChE mRNA levels after PNS neuronal injury.

\section{Materials and Methods}

Animal care and surgical procedures. Production and characterization of human $\mathrm{HuD}$-overexpressing transgenic mice has been described in detail previously (Bolognani et al., 2006). Briefly, the complete human $\mathrm{HuD}$ cDNA sequence (Szabo et al., 1991) with an N-terminal myc tag inserted downstream of the $\mathrm{Ca}^{2+} /$ calmodulin kinase II $\alpha$-subunit ( $\alpha$-CaMKII) promoter was used to generate the transgenic mice. Two lines were used in these studies, a low expresser $(\mathrm{HuD} 2)$, which was used as a control for some experiments, and a high expresser (HuD4).

Female Sprague Dawley rats weighing 150-200 g were obtained from Charles River Laboratories (Québec, Canada) and housed in a $12 \mathrm{~h}$ light/ dark cycle with access to standard food and water ad libitum. Rats were anesthetized by gas inhalation with halothane, and superior cervical ganglion (SCG) axotomy was performed by cutting the internal and external carotid nerves $\sim 2-5 \mathrm{~mm}$ from the ganglion body. In sham-operated animals, the SCG was exposed, but the nerves remained intact and untouched. These SCGs were used as controls. Sham-operated and axotomized SCGs were removed from anesthetized animals 1, 2, and $4 \mathrm{~d}$ after axotomy. Success of the axotomy was determined by resulting ptosis of the ipsilateral eyelid. For HuD viral expression studies, $4 \mu \mathrm{l}\left(1 \times 10^{7}\right.$ particles/ml) of herpes simplex virus (HSV) containing either the LacZ sequence (HSV-LacZ) (Neve et al., 1997) or the myc-tagged human HuD sequence (HSV-HuD) (Anderson et al., 2001) was injected into SCGs using a 27 gauge needle attached to a Hamilton syringe and the Harvard Apparatus (Holliston, MA) PHD 2000 Infuse/Withdraw syringe pump at a rate of $1.5 \mu \mathrm{l} / \mathrm{min}$. Axotomy was performed on the SCG $4 \mathrm{~d}$ after viral infection. HSV was prepared and tittered as described previously (Anderson et al., 2001). All tissues were stored at $-80^{\circ} \mathrm{C}$ until use. Animal care and surgical procedures were performed in accordance with the guidelines established by the Canadian Council on Animal Care.

$R N A$ extraction and reverse transcription-PCR. Total RNA was isolated from three to four SCGs or from different brain regions of HuD transgenic mice using a Kontes glass tissue homogenizer and $1 \mathrm{ml}$ of TRIzol reagent (Invitrogen, Burlington, Ontario, Canada) according to the manufacturer's instructions and as described previously (Michel et al., 1994; Boudreau-Lariviere et al., 2000). All RNA samples were stored at $-80^{\circ} \mathrm{C}$ until use. RNA from each sample was quantified using the Gene Quant II RNA/DNA spectrophotometer (Amersham Biosciences, Piscataway, NJ) and adjusted to a final concentration of $80 \mathrm{ng} / \mu \mathrm{l}$.

Reverse transcription of RNA and quantitative PCR were performed as described previously (Jasmin et al., 1993; Michel et al., 1994; BoudreauLariviere et al., 2000). cDNAs corresponding to AChE, GAP-43, HuD, and S12 ribosomal protein (S12; used as an internal control) were amplified as described in detail previously (Jasmin et al., 1993; Michel et al., 1994; Boudreau-Lariviere et al., 1996; Mobarak et al., 2000; Angus et al., 2001). Primers for AChE, GAP-43, and S12 were synthesized based on available sequences and amplified products of 670,737, and $368 \mathrm{bp}$, respectively (Forster et al., 1993; Legay et al., 1993; Mobarak et al., 2000).
The HuD 5' and $3^{\prime}$ primers (5', ACGCATCCTGGTTGATCAAG; 3', AGAGGACACTCTCATCAGAATCAG) were designed based on available sequences (GenBank accession number NM_010488.1), and amplified products corresponded to $\mathrm{HuD}_{\text {pro }}$ (456 bp) and $\mathrm{HuD}$ (411 bp). PCR cycling parameters consisted of an initial denaturation at $94^{\circ} \mathrm{C}$ for $1 \mathrm{~min}$; followed by a $1 \mathrm{~min}$ annealing step at $54^{\circ} \mathrm{C}$ for $\mathrm{S} 12$, at $55^{\circ} \mathrm{C}$ for GAP-43, at $60^{\circ} \mathrm{C}$ for $\mathrm{HuD}$, and at $70^{\circ} \mathrm{C}$ for $\mathrm{AChE}$; and a 2 min extension step at $70^{\circ} \mathrm{C}$ for $\mathrm{AChE}$ or a $1 \mathrm{~min}$ extension step at $72^{\circ} \mathrm{C}$ for $\mathrm{S} 12, \mathrm{HuD}$, and GAP-43. This was followed by a $10 \mathrm{~min}$ elongation step at $72^{\circ} \mathrm{C}$.

PCR products were visualized on ethidium bromide-stained $1.5 \%$ agarose gels and quantified using the fluorescent dye VistraGreen (Amersham Biosciences). Quantitative analysis was performed using a Storm PhosphorImager and the accompanying ImageQuaNT software (Molecular Dynamics, Sunnyvale, CA). The values obtained for AChE, GAP-43, and $\mathrm{HuD}\left(\mathrm{HuD}_{\text {pro }}\right.$ and $\mathrm{HuD}$ combined) were standardized to those obtained with S12 in the same sample and expressed as a percentage of the control (sham-operated) sample. All reverse transcription (RT)-PCRs aimed at determining the relative abundance of AChE, GAP-43, and $\mathrm{HuD}$ mRNAs were performed during the linear range of amplification. All samples, including the negative control, were prepared using common master mixes containing all of the RT and PCR reagents and were run in parallel. In all experiments, PCR products were never detected in the negative control.

In situ hybridization. In situ hybridization (ISH) was performed on $10-\mu \mathrm{m}$-thick frozen sections of adult mouse brains using a modified version of a detailed previously published protocol (Young et al., 1998). Briefly, sense and antisense cRNA probes were synthesized by in vitro transcription using T7 or T3 RNA polymerase (Promega, Madison, WI), respectively, and ${ }^{35} \mathrm{~S}$-UTP and ${ }^{35} \mathrm{~S}$-CTP radiolabeled nucleotides (Amersham Biosciences). The cDNA sequence encoding parts of AChE exon 6 and the $3^{\prime}$-UTR (nucleotides 1476-1987 of the AChE mRNA sequence; accession number S50879) were inserted in frame in the pBS II-SK vector and used as template cDNA for in vitro transcription. Radiolabeled cRNA probes were separated from unincorporated nucleotides using NAP-5 Columns (Amersham Biosciences), precipitated, and stored in hybridization buffer ( $50 \%$ formamide, $300 \mathrm{~mm} \mathrm{NaCl}, 20 \mathrm{~mm}$ Tris- $\mathrm{HCl}, 5 \mathrm{~mm}$ EDTA, pH 8.0, 10\% dextran sulfate, $1 \times$ Denhardt's solution, $50 \mu \mathrm{g} / \mathrm{ml}$ yeast tRNA, and $10 \mathrm{~mm}$ DTT) at $-80^{\circ} \mathrm{C}$ until use. The sections were hybridized overnight with $2 \times 10^{4} \mathrm{cpm} / \mu \mathrm{l}$ of probe in $25-30 \mu \mathrm{l}$ of hybridization buffer and washed as described previously (Young et al., 1998). Dehydrated and air-dried slides were dipped in NTB2 (Kodak, Rochester, NY) autoradiographic emulsion and exposed for $14 \mathrm{~d}$. The slides were subsequently developed in Kodak Dektol developer. The labeled sections were viewed and photographed using a Zeiss (Thornwood, NY) Axiophot microscope.

In vitro $m R N A$ stability assay. In vitro mRNA stability assay was performed using a protocol adapted from other publications (PerroneBizzozero et al., 1991; Ford and Wilusz, 1999; Mobarak et al., 2000). Briefly, total RNA was obtained from PC12 cells differentiated in the presence of NGF for $72 \mathrm{~h}$ as described previously (Deschênes-Furry et al., 2003). Total protein was extracted from sham-operated or $2 \mathrm{~d}$ axotomized SCGs (see below for procedure). Total RNA from PC12 cells $(0.4$ $\mu \mathrm{g} / \mu \mathrm{l})$ was incubated with total SCG proteins $(0.1 \mu \mathrm{g} / \mu \mathrm{l})$ in a final volume of $200 \mu \mathrm{l}$ at $37^{\circ} \mathrm{C}$ in stability buffer [1× MOPS (4morpholinepropanesulfonic acid), $1 \mathrm{~mm}$ ATP, $0.1 \mathrm{~mm}$ spermine, $2 \mathrm{~mm}$ DTT, and $1 \mathrm{U} / \mu \mathrm{l}$ RNase inhibitor]. At intervals of $0,5,10,30$, and $60 \mathrm{~min}$, a $40 \mu \mathrm{l}$ aliquot was removed, and the reaction was stopped by the addition of ice-cold phenol/chloroform. The time 0 aliquot was removed promptly after mixture of the protein and RNA. Deproteination and precipitation of the RNA were then performed in the presence of $2 \mu \mathrm{g}$ of oyster glycogen. RNA was stored at $-80^{\circ} \mathrm{C}$ until use for RT-PCR and quantified as described above.

Protein extraction. Total protein was obtained from SCGs using a Kontes glass tissue homogenizer and 250-500 $\mu \mathrm{l}$ of homogenization buffer (0.34 m sucrose, $60 \mathrm{~mm} \mathrm{NaCl}, 15 \mathrm{~mm}$ Tris- $\mathrm{HCl}, \mathrm{pH}$ 8.0, $10 \mathrm{~mm}$ EDTA, and protease inhibitor mixture). The resulting homogenate was sonicated ( $10 \mathrm{~s}$ pulse at $50 \%$ duty cycle and a power output of 1 using the Branson Sonifier 450) and centrifuged $\left(12,000 \times g\right.$ for $15 \mathrm{~min}$ at $\left.4^{\circ} \mathrm{C}\right)$. After centrifugation, the supernatant was recovered, and protein concentra- 
tion was quantified using the Bradford assay (Bio-Rad, Hercules, CA). Aliquots of total protein were stored at $-80^{\circ} \mathrm{C}$ until use.

GST-HuD vector and protein purification. The glutathione $S$-transferase (GST)-HuD vector was prepared by inserting the human $\mathrm{HuD}$ sequence excised from the pcHuD vector (Mobarak et al., 2000), using the BamHI sites flanking the sequence, into the pGEX 4T1 vector using the same restriction enzyme sites. The resulting vector was sequenced, and insert orientation was verified. GST-tagged HuD was produced and purified using the GST Microspin Purification Module kit (Amersham Biosciences) according to the manufacturer's instructions.

In vitro transcription. cDNAs encoding the AChE $3^{\prime}$-UTR were obtained by PCR amplification of the plasmid template pGL3-3'-UTR as described previously (Boudreau-Lariviere et al., 2000; Deschênes-Furry et al., 2003). The primers used to amplify the small fragment encompassing the adenylate- and uridylate-rich element (ARE; 64 nucleotides) and to amplify the region of the GAP-43 3'-UTR known to interact with $\mathrm{HuD}$ (209 nucleotides) (Chung et al., 1997) were designed to include a T7 promoter. Radiolabeled AChE 3'-UTR transcript fragments were synthesized using $\alpha-{ }^{32} \mathrm{P}-\mathrm{UTP}$ (Amersham Biosciences) and an in vitro T7 transcription system (Promega) according to the manufacturer's instructions.

Biotin-labeled CTP (Biotin-14-CTP; Invitrogen) was used to synthesize nonradioactive-labeled transcripts for mRNA-binding protein pulldown assays. Biotin-labeled CTP consisted of 20 and $40 \%$ of the CTP used in the in vitro transcription reaction for the ARE, full-length (FL) AChE 3'-UTR, and FL GAP-43 3'-UTR, respectively. In vitro transcription with biotin-labeled CTP was performed using the MEGAscript T7 or SP6 transcription system (Ambion, Austin, TX) according to the manufacturer's instructions.

Electrophoretic mobility shift assay, UV-cross-linking assay, and mRNAbinding protein pull-down assay. RNA-based electrophoretic mobility shift assays (REMSAs), UV-cross-linking (UV-XL) assays, and mRNAbinding protein pull-down assays were performed using total protein extracts obtained from pooled ( $\sim 14$ SCGs) sham-operated and $2 \mathrm{~d}$ axotomized rat SCGs. REMSAs were performed as described previously (Wilson and Brewer, 1999; Hew et al., 2000; Alterio et al., 2001). Briefly, $20 \mu \mathrm{g}$ of protein extract, or $200 \mathrm{~mm}$ GST-HuD construct, or GST alone was incubated at $37^{\circ} \mathrm{C}$ for 20 min with $2 \times 10^{5} \mathrm{cpm}$ of ${ }^{32} \mathrm{P}$-labeled AChE $3^{\prime}$-UTR fragment in $2 \times$ binding buffer (20 mm HEPES, pH 7.9, 3 mм Mg-acetate, $50 \mathrm{~mm}$ K-acetate, $1 \mathrm{~mm}$ DTT, $5 \%$ glycerol, $0.2 \mu \mathrm{g} / \mu \mathrm{l}$ yeast tRNA, and $2.5 \mu \mathrm{g} / \mu \mathrm{l}$ heparin) in a total volume of $20 \mu \mathrm{l}$. The mixture was separated by $6 \%$ native PAGE with $0.5 \times$ Tris borate-EDTA running buffer. The gels were subsequently dried under vacuum at $80^{\circ} \mathrm{C}$ for $1 \mathrm{~h}$ and exposed to $\mathrm{x}$-ray film at $-70^{\circ} \mathrm{C}$.

UV-XL assays were performed similarly to the REMSAs, with the exception that the complexes formed between the protein extract and radiolabeled 3'-UTR fragments were cross-linked under $254 \mathrm{~nm}$ UV light using the CL-1000 Ultraviolet Crosslinker (UVP, Upland, CA). The cross-linked complexes were then treated with $0.5 \mathrm{U}$ of RNase T1 (Calbiochem, La Jolla, CA) and $1 \mu \mathrm{g}$ of RNase A (Qiagen, Mississauga, Ontario, Canada) for $20 \mathrm{~min}$ at $37^{\circ} \mathrm{C}$. After RNase treatment, SDS-loading buffer was added to each sample, and the samples were separated by $10 \%$ SDS-PAGE. To ensure that equivalent amounts of protein were loaded for each sample, the gels were stained with Coomassie blue before being dried. The gels were dried at room temperature between two sheets of cellophane and exposed to $\mathrm{x}$-ray film at $-70^{\circ} \mathrm{C}$.

mRNA-binding pull-down assays were performed similarly to the REMSAs. Biotin-labeled mRNA ( $2 \mu \mathrm{g})$ was incubated with protein extracts $(100 \mu \mathrm{g})$ that had been precleared with streptavidin-coated Dynabeads (Dynal Biotech, Oslo, Norway) for $30 \mathrm{~min}$ at room temperature in $2 \times$ binding buffer (see above). The RNA-protein reaction was incubated for $1 \mathrm{~h}$ at $4^{\circ} \mathrm{C}$ with streptavidin-coated Dynabeads. The supernatant was collected and stored for future use in Western blots. The beads were washed several times with $1 \times$ binding buffer and resuspended in $1 \times$ binding buffer and SDS-loading dye. The pulled-down proteins were used in Western blots (see below).

Northwestern analyses. Northwestern analyses were performed as described in detail previously (Sagesser et al., 1997; Erondu et al., 1999). Briefly, $50 \mu \mathrm{g}$ of total protein extract was separated by SDS-PAGE using a 10\% gel and electroblotted onto a nitrocellulose membrane (Bio-Rad). The membrane was then incubated in renaturation buffer $[15 \mathrm{~mm}$ HEPES, pH 7.9, $50 \mathrm{~mm} \mathrm{KCl,} 0.1 \mathrm{~mm} \mathrm{MnCl}_{2}, 0.1 \mathrm{~mm} \mathrm{ZnCl}_{2}, 0.1$ mм EDTA, $0.5 \mu \mathrm{M}$ DTT, and $0.1 \%$ (v/v) Igepal CA-630 (a Nonidet P-40 substitute) in RNase-free water] at $4^{\circ} \mathrm{C}$ overnight. The membranes were prehybridized for $1 \mathrm{~h}$ at room temperature in renaturation buffer containing 0.2 $\mathrm{mg} / \mathrm{ml}$ yeast tRNA and hybridized for $4 \mathrm{~h}$ at $4^{\circ} \mathrm{C}$ in renaturation buffer including yeast tRNA, $5 \mathrm{mg} / \mathrm{ml}$ heparin, and $1 \times 10^{6} \mathrm{cpm} / \mathrm{ml}$ RNA probe corresponding to the ARE. The membranes were exposed to $\mathrm{x}$-ray film at $-70^{\circ} \mathrm{C}$ after several washes in renaturation buffer. To ensure that equivalent amounts of proteins were loaded for each sample, the membranes were stained with Ponceau S (Sigma, St. Louis, MO) after exposure to $\mathrm{x}$-ray film.

Immunoprecipitation and $m R N A$ analysis. Immunoprecipitation of the $\mathrm{HuD}$ transgene protein product from a hippocampal protein extract of the $\mathrm{HuD}$ transgenic mice (see above) was performed using protocols adapted from Tenenbaum et al. (2002) and Mobarak et al. (2000). Proteins were extracted from hippocampal tissues using a polysome lysis buffer [100 mм KCl, $5 \mathrm{~mm} \mathrm{MgCl}_{2}, 10$ mм HEPES, pH 7.0, 0.5\% Igepal CA 630, $1 \mathrm{~mm}$ DTT, $1 \mathrm{mg} / \mathrm{ml}$ pepstatin A, Mini-complete, EDTA-free protease inhibitor mixture (Roche Applied Science, Québec, Canada), and $100 \mathrm{U} / \mathrm{ml}$ Rnasin (Promega)]. Protein extracts were centrifuged $\left(12,000 \times g\right.$ for $15 \mathrm{~min}$ at $\left.4^{\circ} \mathrm{C}\right)$, and resulting supernatants were aliquoted and kept at $-80^{\circ} \mathrm{C}$ until use. Cytoskeletal fractions were obtained from the pellets by resuspending them in $0.1 \%$ SDS containing lysis buffer, followed by the addition of excess nonionic detergent. The solution was centrifuged again, and the resulting was supernatant aliquoted and stored at $-80^{\circ} \mathrm{C}$ until use.

For immunoprecipitations, $500 \mu \mathrm{g}$ of total proteins or $250 \mu \mathrm{g}$ of the cytoskeletal fraction was first precleared with $1 \mu \mathrm{g}$ of normal mouse IgG (Santa Cruz Biotechnology, Santa Cruz, CA) and $20 \mu \mathrm{l}$ of protein G Dynabeads (Dynal Biotech) in immunoprecipitation buffer $(20 \mathrm{~mm}$ Tris, $\mathrm{pH}$ 7.0, $50 \mathrm{~mm} \mathrm{NaCl}, 3 \mathrm{~mm} \mathrm{Mg}$-acetate, $100 \mu \mathrm{M} \mathrm{ZnCl}_{2}, 1 \%$ Igepal CA-630, $1 \%$ BSA, $10 \mu \mathrm{g} / \mathrm{ml}$ yeast tRNA, 5 mм EDTA, 1 mm DTT, and $100 \mathrm{U} / \mathrm{ml}$ Rnasin) for $1 \mathrm{~h}$ at room temperature with constant mixing. The resulting supernatant was incubated with $2 \mu \mathrm{g}$ of anti-myc antibody (Roche Applied Science) or an equivalent amount of normal mouse IgG at room temperature with constant mixing for $2 \mathrm{~h}$. The reaction mixture was subsequently added to $30 \mu \mathrm{l}$ of protein G Dynabeads and incubated at room temperature with constant mixing for $1 \mathrm{~h}$. After this incubation, the beads were washed several times with immunoprecipitation buffer, and total RNA was extracted from the pellet using TRIzol reagent as described above. The extracted RNA was subsequently used for RT-PCR using the Omniscript Reverse Transcription kit (Qiagen) and HotStarTaq DNA polymerase (Qiagen) as recommended by the manufacturer and as described above.

For GST-HuD immunoprecipitation and RT-PCR, $1 \mu \mathrm{g}$ of GST-HuD or GST was incubated with $5 \mu \mathrm{g}$ of RNA extracted from sham-operated SCGs at room temperature in binding buffer (described above) for 20 $\mathrm{min}$. The reaction mixture was precleared and immunoprecipitated using anti-HuD antibody 16C12 (Clonegene, Hartford, CT). Bound RNA was extracted and used for RT-PCR as described above.

Western blot. For Western blotting, 20-25 $\mu$ g of protein extract obtained from mouse hippocampus (see above), sham-operated, and $2 \mathrm{~d}$ axotomized SCGs or from the mRNA-binding protein pull-down assays were denatured in SDS-loading buffer and subjected to 10\% SDS-PAGE. Proteins were then transferred onto a nitrocellulose membrane (Bio$\mathrm{Rad}$ ). After transfer, the membranes were incubated with antibodies directed to the myc epitope (Roche Applied Science), HuD (Clonegene), neuronal $\mathrm{Hu}$ proteins (Invitrogen, Eugene, OR), or $\alpha$-tubulin (Sigma) and revealed using the SuperSignal ECL kit (Pierce, Rockford, IL).

Statistical analysis. An ANOVA was performed to evaluate the effects of SCG axotomy and HuD viral expression on AChE mRNA levels. The Fisher's least square difference test was used to determine whether the differences seen between group means were significant. An unpaired Student's $t$ test was performed to evaluate the effects of human HuD transgene expression in the hippocampus on the levels of AChE mRNA. The level of significance in both analyses was set at $p<0.05$. Data are expressed as mean $\pm \mathrm{SE}$ throughout. 
A
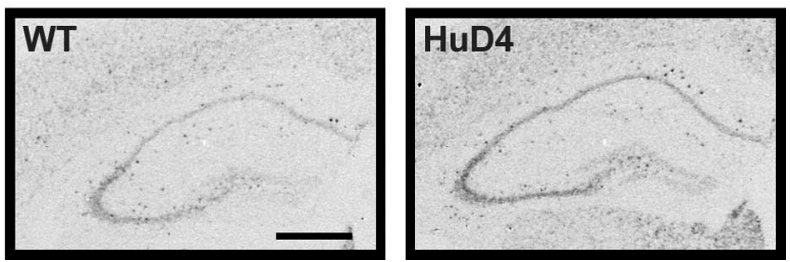

Figure 1. Expression of $A C h E m R N A$ is increased in the hippocampus of HuD-overexpressing transgenic mice. ISH for AChE mRNA was performed on coronal brain sections from wild-type (WT) and HuD-overexpressing transgenic (HuD4) mice using a radiolabeled antisense cRNA probe to AChE encompassing part of exon 6 through to the 3'-UTR. Scale bar, $500 \mu \mathrm{m}$.

\section{Results}

HuD binds AChE transcripts in vivo

In a first series of experiments, we examined whether $\mathrm{HuD}$ binds AChE and regulates AChE mRNA levels in vivo. To this end, we first examined expression levels of AChE mRNA in the CNS of the recently described transgenic mice that overexpress human $\mathrm{HuD}$ in specific subpopulations of neurons (Bolognani et al., 2006). For these studies, we focused on the HuD4 line of transgenic mice (high expresser), whose $\mathrm{HuD}$ protein levels were twofold greater than control littermates and whose myc-tagged transgene product was up to fourfold greater than the HuD2 line (low expresser) that expressed the lowest amount of transgene product (see Fig. 2A) (Bolognani et al., 2006). As well, because the human $\mathrm{HuD}$ transgene product was primarily expressed in the forebrain, as a result of the expression pattern of the promoter ( $\alpha$-CaMKII) driving transgene levels, we concentrated on the hippocampus for these studies.

As shown in Figure 1, using ISH we observed that AChE mRNA was expressed in the hippocampal neurons corresponding to the CA1-CA3 rostrocaudal axis, with very little expression in the dentate gyrus in both wild-type and $\mathrm{HuD} 4$ transgenic brains. The AChE mRNA grain density was clearly greater in the $\mathrm{HuD} 4$ transgenic mouse hippocampus than in the wild type, suggesting that these neurons expressed an increased amount of AChE mRNA. This observation was verified by quantitative RTPCR performed on hippocampal brain regions, demonstrating that there was, in fact, a significant $(p<0.05 ; n=2$ and 3 different brain samples for wild type and $\mathrm{HuD} 4$, respectively) twofold to threefold increase in AChE mRNA levels in the HuD4 transgenic hippocampus (data not shown). In complementary experiments, we examined the mRNA levels in the cerebellum/ brainstem areas by RT-PCR and ISH. We found that AChE mRNA levels were also significantly increased by $\sim$ fourfold in $\mathrm{HuD} 4$ transgenic cerebellum/brainstem regions (data not shown), most likely corresponding to cranial nerve nuclei in brainstem expressing high levels of AChE. Together, these results demonstrate that increased expression of $\mathrm{HuD}$ is associated with a concomitant increase in AChE transcript levels.

Given these results, we determined whether the transgene product expressed in the hippocampus could directly bind AChE transcripts. To this end, we used an antibody to the N-terminal myc epitope tag to immunoprecipitate the HuD transgene product from hippocampus cytoskeletal and cytosolic protein extracts of $\mathrm{HuD} 2$ and $\mathrm{HuD} 4$ transgenic mice and extracted the mRNA bound by $\mathrm{HuD}$. Immunoblots for the myc epitope tag demonstrated and confirmed that $\mathrm{HuD} 4$ transgenic mice express considerably more $\mathrm{HuD}$ transgene product than the HuD2 line (Fig. $2 A)$. As shown in Figure $2 B$, AChE transcripts were extracted and
A
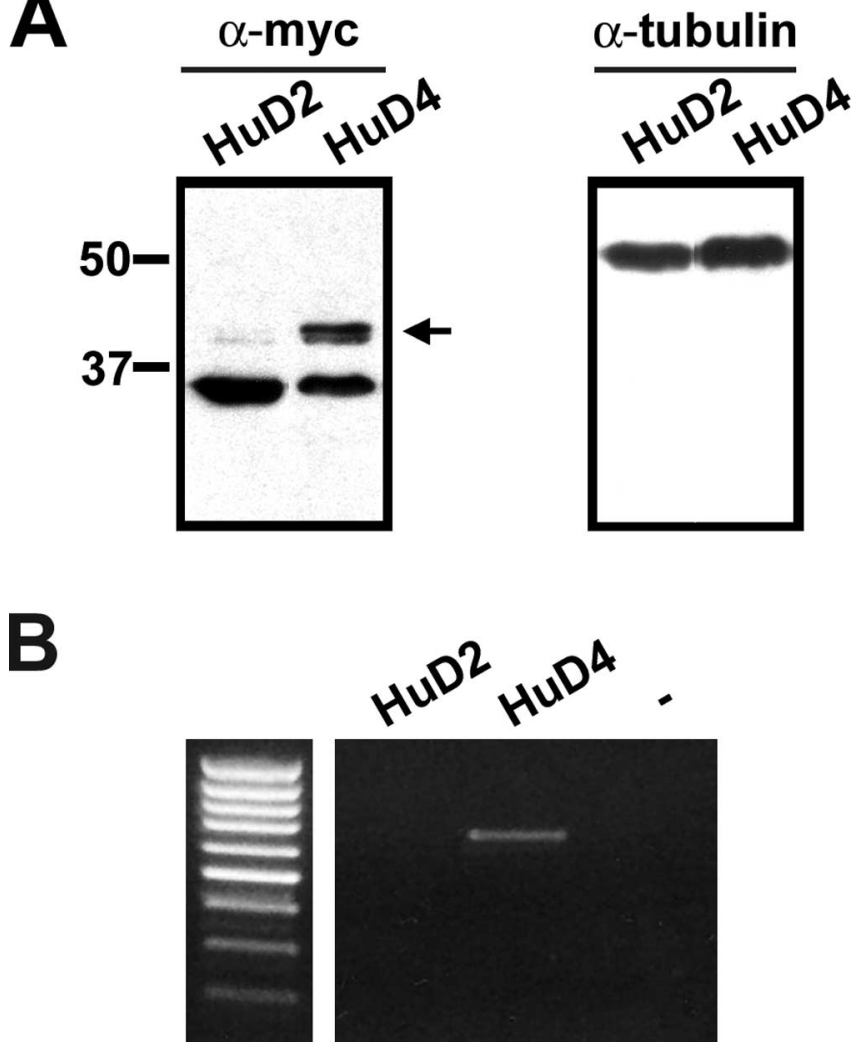

Figure 2. The HuD transgene product in HuD4 transgenic mice binds endogenous AChE mRNA. $\boldsymbol{A}$, Immunoblots for myc-tagged HuD (left) and $\alpha$-tubulin (right; to verify equal loading) were performed on total protein extracts from HuD2 and HuD4 transgenic mice hippocampus. The arrow indicates the bands corresponding to HuD splice variants. The lower band corresponds to nonspecific antibody interactions. The myc-tagged HuD transgene product was immunoprecipitated using an antibody directed to the myc epitope from cytoskeletal HuD2 and HuD4 transgenic mice hippocampus protein extracts. The bound mRNA was extracted, and RT-PCR for AChE was performed. $\boldsymbol{B}$, Representative ethidium bromide-stained agarose gel displaying the $A C h E P C R$ product. - , Negative control.

amplified from the HuD4 cytoskeletal protein immunoprecipitate but were hardly detectable in the $\mathrm{HuD} 2$ immunoprecipitate because of the relatively low level of myc-tagged human $\mathrm{HuD}$ present in the HuD2 line (Bolognani et al., 2006). This result serves as an ideal negative control for the immunoprecipitation assay, in that AChE mRNAs are not binding nonspecifically to the antibody or protein $\mathrm{G}$ dynabeads. In addition, we could only successfully extract and amplify AChE mRNA from the HuD4 cytoskeletal immunoprecipitate, which suggests, as demonstrated previously, that $\mathrm{HuD}$ and its associated transcripts are predominantly associated with the cytoskeleton (Pascale et al., 2004). These results, together with those from Figure 1, represent the first demonstration that $\mathrm{AChE} \mathrm{mRNA}$ is associated with $\mathrm{HuD}$ in vivo.

Axonal injury results in decreased AChE mRNA levels Next, we examined the role of post-transcriptional mechanisms and $\mathrm{HuD}$ in regulating $\mathrm{AChE}$ transcript levels after neuronal injury. For these experiments, we used the sympathetic neurons from rat SCG. This model was chosen for multiple reasons: (1) the adrenergic neurons of the SCG receive predominantly cholinergic inputs and express high levels of AChE; (2) the structure of this ganglion consists of a single major site of input and two major sites of output (internal and external carotid nerves), allowing for simple manipulation; (3) its peripheral location allows 


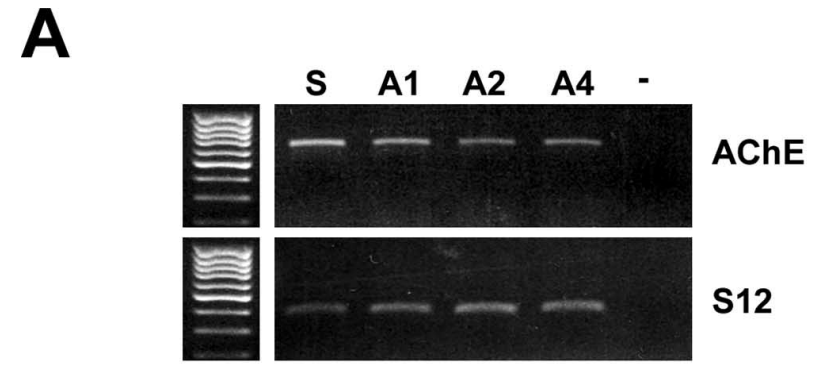

B

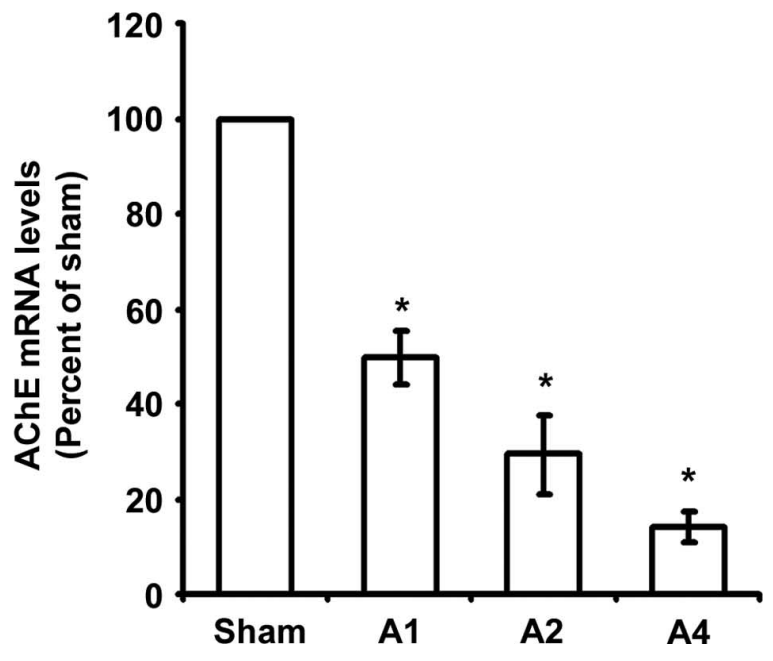

Figure 3. AChE expression levels decrease after axotomy of rat SCG. $A$, Example of ethidium bromide-stained agarose gels displaying $A C h E$ and $S 12$ ribosomal protein (S12) PCR products from sham-operated (S) and 1, 2, and 4 d axotomized SCGs. - , Negative control. B, Quantification of AChE mRNA levels in Sham and 1, 2, and 4 d axotomized SCGs, expressed as a percentage of sham-operated SCGs. ${ }^{*} p<0.0001$, significant differences from sham-operated SCG ( $n=3-4$ independent experiments). A1, A2, and A4 are 1, 2, and 4 d axotomized SCG, respectively.

for easy accessibility; and (4) the synaptic structure of these sympathetic neurons is similar to those of the CNS (Klimaschewski et al., 1994, 1996; Taxi and Eugene, 1995). Neuronal injury (axotomy) was achieved with this model by cutting the internal and external carotid nerves as they exit from the ganglion body. The success of axotomy was determined by ptosis of the ipsilateral eyelid and by the concomitant decrease in tyrosine hydroxylase transcript levels (data not shown) (Sun and Zigmond, 1996).

Although initial studies have demonstrated that SCG axotomy resulted in an $\sim 60 \%$ decrease in AChE protein activity (Klingman and Klingman, 1969; Viana and Kauffman, 1984), the effect of axotomy on the underlying molecular mechanisms remains poorly defined. Thus, we examined the initial response of AChE mRNA to SCG axotomy. Because the AChE T transcript is predominantly expressed in neurons, we focused on the level of expression of this mRNA (Legay et al., 1993; Seidman et al., 1995). As illustrated in Figure 3, AChE mRNA levels decreased dramatically to $\sim 50 \%$ of sham-operated levels $(p<0.0001)$ within $1 \mathrm{~d}$ of axotomy. Transcript levels continued to decrease gradually, such that the levels observed within 2 and $4 \mathrm{~d}$ of axotomy were $\sim 30$ and $15 \%$ ( $p<0.0001)$ of those in sham-operated SCGs, respectively. The relative amount of S12 ribosomal protein mRNA, used as an internal control for these assays, did not vary significantly during this period.
A
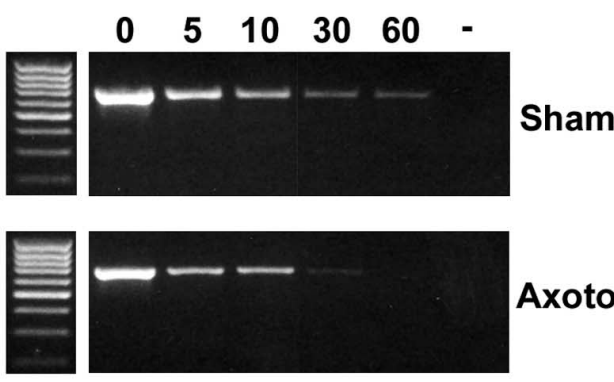

Axotomy

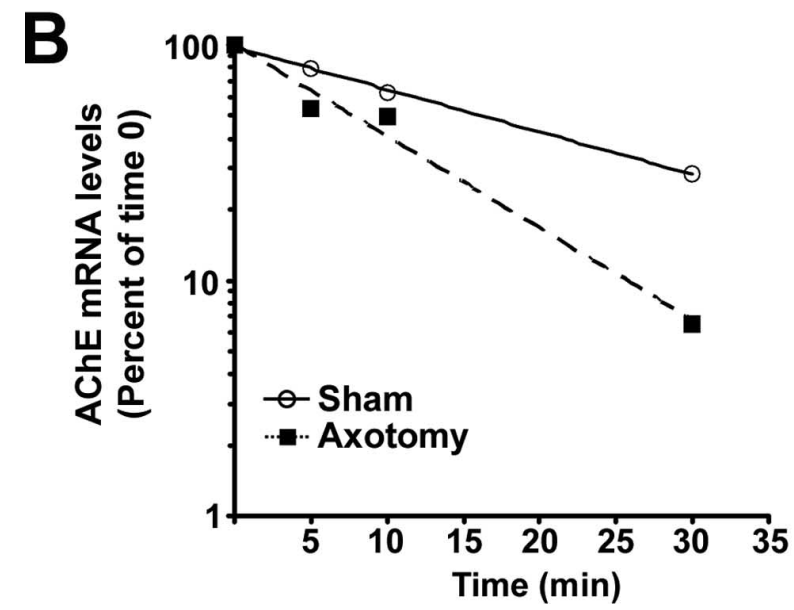

Figure 4. Decline in AChE mRNA levels is accelerated after axotomy of rat SCG. $A$, Example of ethidium bromide-stained agarose gels displaying $A C h E P C R$ products from in vitro mRNA stability assay performed using total RNA from differentiated PC12 cells incubated for $0,5,10,30$, or 60 min with total proteins extracted from sham-operated (Sham) and $2 \mathrm{~d}$ axotomized (Axotomy) SCGs. B, Quantification of the remaining AChE mRNA levels after the indicated incubation times expressed as a percentage of the mRNA level at time $0(100 \%)$.

\section{Axotomy results in decreased AChE mRNA stability}

Given these observations, we subsequently considered whether axotomy of the SCG also affected post-transcriptional regulation of AChE. Therefore, we first performed in vitro mRNA stability assays to determine whether proteins from sham-operated and $2 \mathrm{~d}$ axotomized SCGs differentially affect AChE mRNA levels. These assays are commonly used to assess the stability of specific transcripts in response to particular stimuli (Kohn et al., 1996; Ford and Wilusz, 1999; Mobarak et al., 2000). To this end, exogenous total RNA from NGF-induced differentiated PC12 cells that have a high level of AChE mRNA was incubated with protein extracts from either sham-operated or $2 \mathrm{~d}$ axotomized SCGs. Aliquots of the protein-RNA reaction mixture were removed at timed intervals, and mRNA was extracted and used for quantitative RT-PCR.

As shown in Figure 4, AChE transcript levels decreased during the course of the incubation period in the presence of protein extracts from sham-operated and $2 \mathrm{~d}$ axotomized SCGs, albeit more rapidly in the presence of axotomized SCG proteins. Figure $4 A$ demonstrates that mRNA extracted from the sham-operated protein-RNA reaction mixture could be amplified at all time points examined. Remaining AChE mRNA levels were expressed as a percentage of the levels determined at time 0 (100\%). Accordingly, under these conditions, the AChE mRNA half-life cor- 
responded to $\sim 20$ min when RNA was incubated with shamoperated SCG proteins. In comparison, AChE mRNA levels were significantly diminished within $30 \mathrm{~min}$ of incubation of the RNA with $2 \mathrm{~d}$ axotomized SCG protein extracts and undetectable by 60 min. The calculated half-life of AChE mRNA when incubated with $2 \mathrm{~d}$ axotomized SCG protein extract was $\sim 10 \mathrm{~min}$. These results therefore suggest that after SCG axotomy there is an alteration in the levels or functions of certain RNA-binding proteins that are important to AChE transcript stability and abundance.

\section{Axotomy alters AChE mRNA and protein interactions}

We performed REMSAs using an in vitro-transcribed 64nucleotide transcript encompassing the ARE (Fig. 5A) to visualize the differential interactions between this domain and RNAbinding proteins. As illustrated in Figure 5B, REMSAs performed using proteins from sham-operated SCGs, resulted in three different complexes (see arrows) that associated with the AChE ARE. To decrease nonspecific interactions, both yeast tRNA and heparin were added to the binding buffer. REMSAs performed with excess cold-labeled ARE (100-fold) competed out the complexes (data not shown). When protein extracts from $2 \mathrm{~d}$ axotomized SCGs were used, the binding intensities for all three complexes were decreased. Notably, the decreased interactions of some of the complexes were more dramatic than others (Fig. $5 B$, second arrow) in the REMSAs performed with $2 \mathrm{~d}$ axotomized SCG protein extracts. The observed banding pattern and decrease in binding intensity were highly reproducible $(n=3$ different REMSAs).

To demonstrate that $\mathrm{HuD}$ protein specifically associated with the ARE, we performed REMSAs with a GST-HuD fusion protein and excess GST domain alone. As shown in Figure 5B, we found that the complex formed between GST-HuD and the ARE corresponded with one of the complexes formed between the ARE and SCG proteins (compare right arrow with left arrow). In addition, this complex appeared to be absent in the REMSA performed with protein extracts from axotomized SCGs. Accordingly, this complex, which possibly corresponds to $\mathrm{HuD}$, exhibits either reduced binding or does not bind to the AChE $3^{\prime}$-UTR after axotomy.

To further demonstrate that $\mathrm{HuD}$ associates with AChE mRNA, we incubated the GST-HuD fusion protein with a total RNA extract isolated from sham-operated SCGs and immunoprecipitated $\mathrm{HuD}$ protein with a $\mathrm{HuD}$-specific antibody (see Materials and Methods) extracted total RNA and used it for RTPCR. As shown in Figure 5C, AChE mRNA could be amplified from the GST-HuD immunoprecipitate. In addition, GAP-43 mRNA, another known target of HuD (Mobarak et al., 2000), was also amplified from the GST-HuD immunoprecipitate (data not shown). However, neither AChE nor GAP-43 transcripts were amplified from the controls, namely excess GST alone, control IgG, or the streptavidin-coated beads, suggesting that the binding was specific. Together, these results strongly support the specificity of the interaction between $\mathrm{HuD}$ and AChE.

Interactions between the ARE and proteins from shamoperated and $2 \mathrm{~d}$ axotomized SCGs were also assessed using $\mathrm{UV}-\mathrm{XL}$ assays and Northwestern analyses. UV-XL assays were performed in a similar manner to the REMSAs, except that the protein-RNA complexes were cross-linked by UV light and proteins making up the complexes were separated by SDS-PAGE, after digestion of the bound and unbound RNA. With the UV-XL assay, we found a protein from sham-operated SCGs of $\sim 40-42$ $\mathrm{kDa}$ that could bind the ARE (Fig. 5D). In comparison, we could not detect any proteins from the $2 \mathrm{~d}$ axotomized SCG extract that

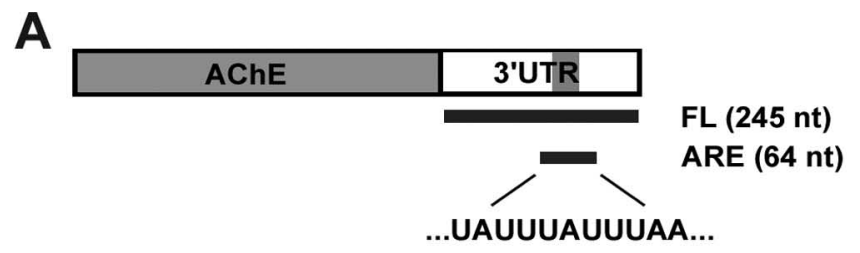

B

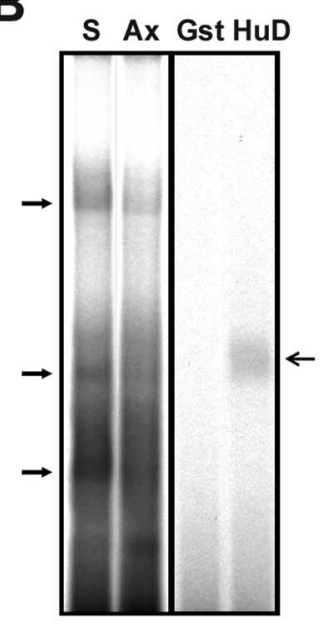

D E

E

S Ax
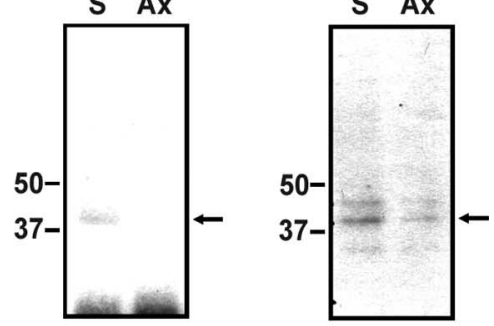

F

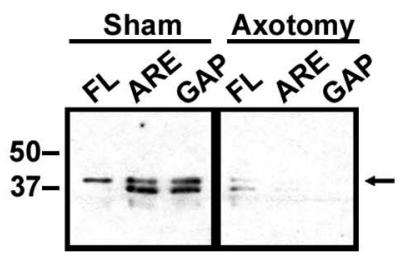

c

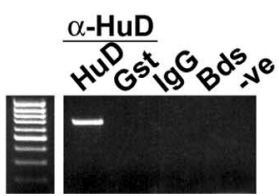

Figure 5. The pattern of protein-RNA interactions with the AChE $3^{\prime}$-UTR changes after axotomy of rat SCG. $A$, Schematic of the $\sim 2.4 \mathrm{~kb}$ AChE transcript including the ARE and its sequence. The FL 3 ' -UTR probe (FL; 245 nucleotides) and ARE probe (64 nucleotides) consisting of the ARE and flanking domains are also shown. nt, Nucleotides. $\boldsymbol{B}$, REMSAs were performed using protein extracts from sham-operated and $2 \mathrm{~d}$ axotomized SCG incubated with the in vitro-transcribed radiolabeled AChE 3 ' -UTR ARE probe in the presence of yeast tRNA and heparin. REMSAs were also performed with the GST-HuD fusion protein and the GST domain alone and the ARE probe (right arrow). Representative autoradiograms demonstrate the interaction between RNA and protein complexes. Right arrows indicate specific RNA-protein complexes that decrease in the axotomy sample. C, Specific interaction between the GST-HuD fusion protein and AChE mRNA found in a sham-operated SCG total mRNA extract is demonstrated by immunoprecipitation of HuD with a HuD-specific antibody and RT-PCR for AChE performed on the immunoprecipitate. The GST moiety (Gst), normal rabbit lgG, and protein G beads (Bds) were used as controls for nonspecific binding. The AChE PCR product obtained is viewed on an ethidium bromide-stained agarose gel. - ve, Negative. $\boldsymbol{D}, \boldsymbol{E}$, Direct binding of specific proteins from sham-operated and 2 d axotomized SCGs to the ARE was examined using UV-XL assays (D) and Northwestern analyses $(\boldsymbol{E})$. Note the decreased binding of an $\sim 40 \mathrm{kDa}$ protein indicated with the arrows. $\boldsymbol{F}$, mRNA-binding protein pull-down assay was performed using biotin-labeled FL AChE 3'-UTR, ARE, and GAP-43 3'-UTR RNAs incubated with protein extracts from shamoperated and $2 \mathrm{~d}$ axotomized (Axotomy) SCGs. Immunoblots for neuronal Hu proteins were performed with proteins pulled down by labeled RNA. Bands corresponding to HuD are indicated with an arrow. Note the presence of Hu proteins binding more specifically to AChE and GAP-43 mRNAs in the sham-operated protein extract than in the axotomized protein extract. S, Sham operated; Ax, 2 d axotomized; HuD, GST-HuD fusion protein.

were directly binding the AChE ARE. Likewise, in the Northwestern analyses, two proteins of that approximate mass from shamoperated and $2 \mathrm{~d}$ axotomized SCG protein extracts bound the ARE. However, binding intensities of the proteins from $2 \mathrm{~d}$ axotomized SCGs were considerably decreased (Fig. 5E).

Finally, direct binding of SCG HuD with the AChE ARE was demonstrated by mRNA-binding protein pull-down assays. In this assay, biotin-labeled RNA corresponding to the FL AChE 
$3^{\prime}$-UTR and the ARE were incubated with protein extracts from sham-operated and $2 \mathrm{~d}$ axotomized SCGs. The resulting complexes were pulled out of solution and used for Western blotting using an antibody directed to all neuronal $\mathrm{Hu}$ proteins: $\mathrm{HuD}$ ( $\sim 40-42 \mathrm{kDa}), \mathrm{HuB}$, and $\mathrm{HuC}(\sim 39 \mathrm{kDa})$ (Marusich et al., 1994; Okano and Darnell, 1997). Based on the amino acid sequence, $\mathrm{HuD}$ has a greater mass than $\mathrm{HuB}$ and $\mathrm{HuC}$. As shown in Figure $5 F$, neuronal $\mathrm{Hu}$ proteins from sham-operated SCG associated with AChE FL and ARE transcripts specifically. The specificity of this interaction was confirmed using the GAP-43 3'UTR, which, as expected, also pulled down neuronal Hu proteins (Fig. 5F) (Mobarak et al., 2000). Note that proteins pulled out of solution by AChE and GAP-43 transcripts had a similar molecular mass to those binding to the ARE as revealed in UV-XL and Northwestern analyses (compare arrow in Fig. $5 F$ with Western blot in Fig. 2 B). This suggests that one of the proteins binding the AChE ARE is indeed HuD. When the pull-down assay was performed with protein extracts from $2 \mathrm{~d}$ axotomized SCGs, transcripts for AChE and GAP-43 showed greatly decreased or no interactions with neuronal $\mathrm{Hu}$ proteins. Together, the results obtained with several different yet complementary approaches indicate that the decrease in AChE mRNA levels after SCG axotomy results from decreased binding of the neuronal $\mathrm{Hu}$ proteins, specifically $\mathrm{HuD}$.

\section{HuD expression is altered after SCG axotomy}

Because we observed decreased binding of proteins of the approximate molecular mass of $\mathrm{HuD}$, we next specifically examined the effect of SCG axotomy on expression of HuD transcripts and protein. The $\mathrm{HuD}$ gene is alternatively spliced at the $3^{\prime}$ end, resulting in three possible transcripts: $\mathrm{HuD}_{\text {pro }}$, which is unspliced; $\mathrm{HuD}$, which lacks exon 7; and $\mathrm{HuD}_{\text {mex }}$, which lacks exons 6 and 7 (for review, see Deschênes-Furry et al., 2006). As shown in Figure $6 A$, sham-operated SCGs expressed $\mathrm{HuD}_{\text {pro }}$ and $\mathrm{HuD}$ transcripts, but to different extents, such that the level of expression of $\mathrm{HuD}$ was greater than that of $\mathrm{HuD}_{\text {pro }}$. As shown in Figure 6, the alternatively spliced $\mathrm{HuD}_{\text {pro }}$ and $\mathrm{HuD}$ transcripts (quantified together by RT-PCR) decrease by $\sim 50 \%$ within $1 \mathrm{~d}$ of axotomy and remained at this low level of expression for up to $4 \mathrm{~d}$. Using antibodies directed to all neuronal $\mathrm{Hu}$ proteins, we observed that the protein levels of the band corresponding to $\mathrm{HuD}$ (Marusich et al., 1994) were decreased to a similar extent as the transcripts in $2 \mathrm{~d}$ axotomized SCGs (data not shown). In addition, the reduction in $\mathrm{Hu}$ protein levels corresponds well with the diminished protein-RNA interactions observed in the UV-XL, Northwestern, and pull-down analyses (compare Figs. $2 B, 5 D-F$ ). These findings therefore indicate that reduced $\mathrm{HuD}$ expression levels as a result of SCG axotomy lead to parallel changes in $\mathrm{HuD}$ binding activity and, consequently, on the overall expression levels of AChE mRNA.

\section{Exogenous expression of $\mathrm{HuD}$ maintains AChE mRNA levels after axotomy}

To explicitly demonstrate the role of $\mathrm{HuD}$ in regulating AChE expression after SCG axotomy, we expressed exogenous human $\mathrm{HuD}$ in SCG neurons using a replication-deficient HSV containing the complete human HuD cDNA (Szabo et al., 1991; Anderson et al., 2001). For this experiment, the virus was injected into the SCG $4 \mathrm{~d}$ before axotomy, and SCGs were removed $2 \mathrm{~d}$ after axotomy for analysis. As shown in Figure 7, we observed that AChE mRNA levels decreased dramatically by $\sim 80 \%$ after axotomy, similarly to what we observed in Figure 3. However, when human $\mathrm{HuD}$ was expressed in the SCG, AChE mRNA levels re-
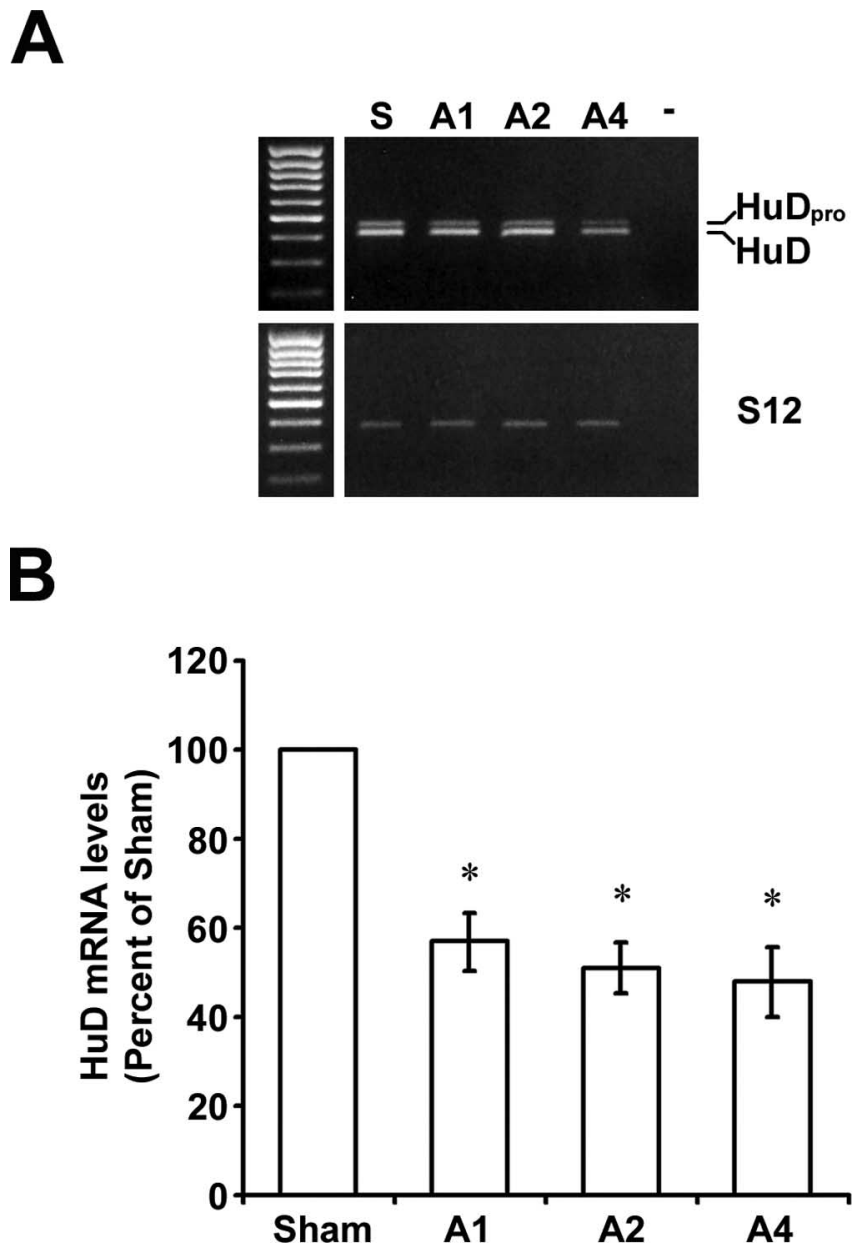

Figure 6. HuD transcript levels decrease after SCG axotomy. $A$, Example of ethidium bromide-stained agarose gels displaying $\mathrm{HuD}$ (top band, $\mathrm{HuD}_{\text {pro; }}$ bottom band, $\mathrm{HuD}$ ) and $\mathrm{S} 12$ ribosomal protein (S12) PCR products from sham-operated (S) and 1, 2, and 4 daxotomized SCG. -, Negative control. $\boldsymbol{B}$, Quantification of $\mathrm{HuD}$ mRNA levels $\left(\mathrm{HuD}_{\text {pro }}\right.$ and HuD quantified together) in sham-operated and 1,2, and $4 \mathrm{~d}$ axotomized SCGs expressed as a percentage of the mRNA levels present in sham-operated SCGs. ${ }^{*} p<0.0001 ; n=3$ independent experiments. $A 1, A 2$, and $A 4$ are 1,2 , and $4 \mathrm{~d}$ axotomized SCG, respectively.

mained unchanged. In fact, they were expressed to the same level as in the sham-operated SCG. When comparing the staining intensity seen in ethidium bromide-stained agarose gels (Fig. 7A), injection of $\mathrm{HuD}-\mathrm{HSV}$ appeared to increase expression levels of AChE transcript in sham-operated SCGs as well. To control for the effects of viral infection, we injected a LacZ-expressing HSV. Injection of the LacZ-expressing HSV did not appear to affect the expression level of AChE transcripts in sham-operated SCGs (Fig. 7A, middle panels) or after axotomy, suggesting that the response to $\mathrm{HSV}-\mathrm{HuD}$ was specific to $\mathrm{HuD}$.

To confirm the compensatory effect of HuD exogenous expression on AChE mRNA levels, we also examined expression of another known $\mathrm{HuD}$ target, GAP-43 mRNA. We observed that GAP-43 mRNA levels decreased in $2 \mathrm{~d}$ axotomized SCGs. Expression of exogenous human $\mathrm{HuD}$ also prevented the decrease in GAP-43 transcript levels. As with AChE, the levels of GAP-43 mRNA appeared greater in sham-operated, HuD-injected SCGs (Fig. 7A), on comparison of the gels. Together, these results clearly demonstrate that expression of human $\mathrm{HuD}$ in the SCG before axotomy can compensate for decreased expression of endogenous $\mathrm{HuD}$ and, accordingly, prevents the reduction in $\mathrm{AChE}$ transcript levels in response to axotomy. 


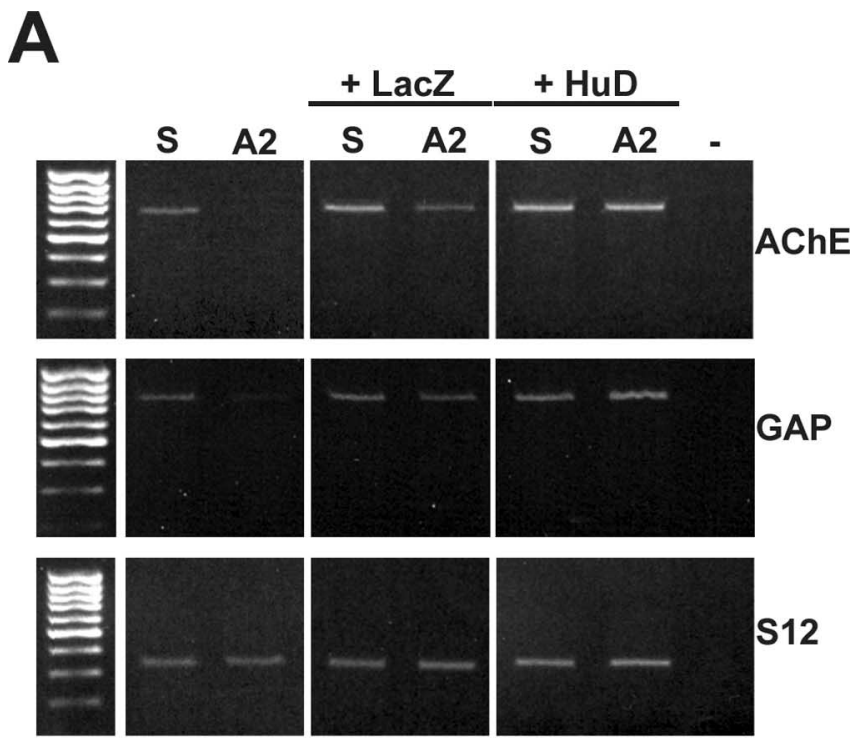

B

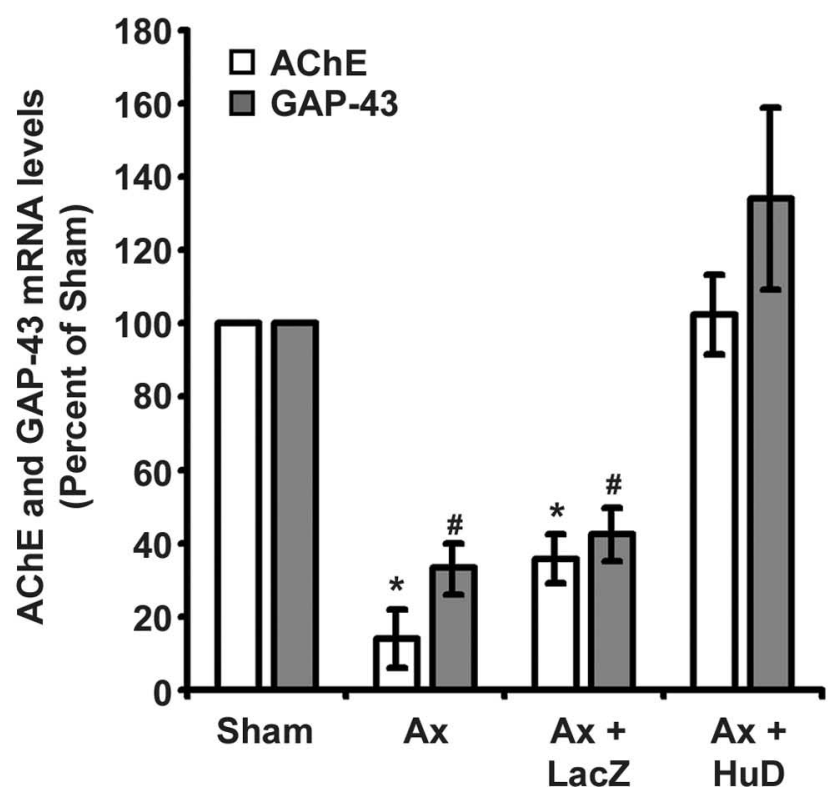

Figure 7. Overexpression of $\mathrm{HuD}$ in the $\mathrm{SCG}$ rescues the expression of $A C h E$ mRNA after axotomy. HSV-HuD and HSV-LaCZ were used to infect both rat SCGs, and axotomy was performed $4 \mathrm{~d}$ later. The SCGs were removed $2 \mathrm{~d}$ after axotomy. $A$, Examples of ethidium bromidestained agarose gels displaying AChE, GAP-43 (GAP), and S12 ribosomal protein (S12) PCR products from sham-operated (S) and $2 \mathrm{~d}$ axotomized (A2) control and HSV-LacZ-infected (+LacZ) or HSV-HuD-infected (+HuD) SCGs. -, Negative control. B, Quantification of AChE and GAP-43 mRNA levels in sham and 2 d axotomized (Ax) control, HSV-LacZ-infected, or HSVHuD-infected SCGs expressed as a percentage of the control or infected sham-operated SCGs. ${ }^{*} p<0.01 ;{ }^{*} p<0.008 ; n=3$ independent experiments.

\section{Discussion}

Numerous studies have previously characterized the expression pattern of AChE molecular forms, activity, and transcripts in neurons of the CNS and PNS (Koelle, 1954; Hosli and Hosli, 1970; Mesulam and Geula, 1991; Hammond et al., 1994; Karpel et al., 1994; Bernard et al., 1995). Although the individual roles of transcriptional and post-transcriptional events are being ad- dressed using various cell-culture systems, there is, in comparison, very little known about the molecular mechanisms controlling AChE expression in neurons in vivo. Given the essential role of AChE in the CNS and PNS, its involvement in various disease states, and its known noncholinergic functions (see Introduction), it appears important to gain insights into the molecular mechanisms regulating AChE expression in vivo. Accordingly, we examined here the interaction between $\mathrm{HuD}$ and AChE mRNAs in vivo in the CNS and PNS and after axotomy of the SCG. Our findings indicate that $\mathrm{HuD}$ directly binds $\mathrm{AChE}$ mRNA and that there is a correspondence between the levels of expression of $\mathrm{HuD}$ and AChE mRNA, such that decreased levels of HuD correlate with decreased AChE mRNA stability and levels after SCG axotomy. To our knowledge, this is the first in vivo study that has clearly demonstrated the occurrence of a specific molecular mechanism involved in regulating AChE expression in neurons.

In vivo studies characterizing the molecular events regulating AChE expression have mostly been performed with skeletal muscle. For example, the dramatic decrease in muscle AChE mRNA levels observed after denervation was attributed to diminished transcript stability as determined by in vitro mRNA stability assays (Grubic et al., 1999; Boudreau-Lariviere et al., 2000). To date, however, the elements and factors mediating this effect have yet to be identified. In comparison, the specific roles of transcriptional and post-transcriptional regulation of AChE, as well as specific elements and factors mediating these effects, have been identified using cultured muscle, neuronal, and hematopoietic cell lines. During differentiation of these cells, posttranscriptional mechanisms corresponding mainly to transcript stability were shown to be a dominant process regulating AChE expression (Fuentes and Taylor, 1993; Luo et al., 1994, 1999; Coleman and Taylor, 1996; Chan et al., 1998; Angus et al., 2001; Deschênes-Furry et al., 2003, 2005). Specifically, an ARE in the AChE $3^{\prime}$-UTR was identified as a target for Hu-family RNAbinding proteins during myogenic and neuronal differentiation (Cuadrado et al., 2003; Deschênes-Furry et al., 2003, 2005). Here, we show that post-transcriptional mechanisms, in particular transcript stability, are also important to AChE mRNA expression in vivo. Specifically, we demonstrated using human HuDoverexpressing transgenic mice and a series of complementary in vitro approaches that $\mathrm{HuD}$ associates with the $\mathrm{ARE}$ in the $\mathrm{AChE}$ 3'-UTR.

AREs are found in 1 in 20 human genes and represent the best-characterized determinants of transcript stability (Chen and Shyu, 1995; Xu et al., 1997; Bakheet et al., 2006). However, whether a transcript will be degraded or stabilized mainly depends on the presence and nature of RNA-binding proteins that recognize and bind the ARE. One of the prevailing theories surrounding transcript turnover mediated via AREs proposes that the relative abundance of stabilizing versus destabilizing RNAbinding proteins governs the stability of target mRNAs (Barreau et al., 2005; Deschênes-Furry et al., 2006). Of the increasing number of identified RNA-binding proteins that bind AREs, HuD and the $\mathrm{Hu}$ family are some of the few that have transcript stabilizing activities. In this regard, after SCG axotomy, we observed using an in vitro mRNA stability assay a marked decline in AChE mRNA stability, which most likely results from changes in the levels or activity of a key RNA-binding protein and a concomitant decrease in $\mathrm{HuD}$ transcript and protein levels. These results therefore indicate that the reduction in AChE transcripts is mostly associated with a decline in $\mathrm{HuD}$ expression, because exogenous expression of $\mathrm{HuD}$ can rescue AChE mRNA levels.

Alteration in transcript stability also occurs because of 
changes in the binding activity of RNA-binding proteins. Accordingly, we observed reduced binding of neuronal $\mathrm{Hu}$ proteins to the ARE using various binding assays. In addition to decreased $\mathrm{HuD}$ expression, the observed decrease in $\mathrm{HuD}$ binding may also result from post-translational modification of $\mathrm{HuD}$, or from interactions with other RNA-binding proteins or structural proteins (Kasashima et al., 1999, 2002; Pascale et al., 2004). For instance, during neuronal differentiation, HuD binding activity can be controlled by the protein kinase $\mathrm{C}$ signaling pathway (Mobarak et al., 2000; Pascale et al., 2005) or through methylation by the methyltransferase CARM1 (coactivator-associated methyltransferase 1) (Fujiwara et al., 2006).

The Hu family of RNA-binding proteins are known to interact with several other proteins, and they are found in ribonucleoprotein complexes often associated with the cytoskeleton (Keene and Tenenbaum, 2002; Pascale et al., 2004). Accordingly, we immunoprecipitated $\mathrm{HuD}$ and $\mathrm{AChE}$ mRNA from hippocampal cytoskeletal protein extracts of $\mathrm{HuD}$-overexpressing transgenic mice. We also observed several RNA-protein complexes that formed with the AChE ARE and SCG protein extracts, suggesting that $\mathrm{HuD}$ may be a member of these complexes or that other RNA-binding proteins are interacting with this domain.

$\mathrm{HuD}$ is one of the neuronal members of the embryonic lethal abnormal vision-like Hu family of RNA-binding proteins (see for review (Guhaniyogi and Brewer, 2001; Perrone-Bizzozero and Bolognani, 2002; Deschênes-Furry et al., 2006). This family of mRNA stabilizing proteins includes the other neuronally expressed members $\mathrm{HuB}$ and $\mathrm{HuC}$ and the ubiquitously expressed HuR. In addition to binding AREs, the RNA-recognition motifs (RRM) of these proteins bind to long poly $(\mathrm{A})$ tails, and the overall binding efficacy of the RRM is modulated by the length of the poly(A) tail (Ma et al., 1997; Beckel-Mitchener et al., 2002; ParkLee et al., 2003; Lopez de Silanes et al., 2004). Given the number and variety of transcripts with AREs, HuD is implicated in multiple neuronal and cellular functions (for review, see DeschênesFurry et al., 2006). For instance, cell-culture studies, and more recently studies performed with $\mathrm{HuD}$ knock-out mice, have demonstrated that $\mathrm{HuD}$ has a significant role in promoting cellcycle exit (Marusich et al., 1994; Okano and Darnell, 1997; Akamatsu et al., 2005), differentiation, and neurite elongation (Aranda-Abreu et al., 1999; Mobarak et al., 2000; Anderson et al., 2001). Within the adult CNS, HuD has also been implicated in the plasticity of hippocampal neurons during various learning paradigms (Quattrone et al., 2001; Bolognani et al., 2004; Pascale et al., 2004).

In this context, expression of several proteins involved in neurite outgrowth and extension, including GAP-43, tau, neurofilament $\mathrm{M}$, and $\mathrm{AChE}$, are regulated by $\mathrm{Hu}$ proteins (Antic et al., 1999; Aranda-Abreu et al., 1999; Mobarak et al., 2000; Deschênes-Furry et al., 2003; Bolognani et al., 2006). Appropriately, we observed that GAP-43 appears coregulated with AChE after axotomy such that GAP-43 transcript stability decreased with axotomy and exogenous expression of $\mathrm{HuD}$ maintained GAP-43 mRNA levels after axotomy. Given these results, it appears therefore that $\mathrm{HuD}$ also plays an essential role in vivo by modulating neurite development.

Many of the studies that have characterized AChE expression in neurons have also described changes in AChE protein, activity, and mRNA that take place in response to axotomy (Klingman and Klingman, 1969; Flumerfelt and Lewis, 1975; Tetzlaff and Kreutzberg, 1984; Viana and Kauffman, 1984; Hoover and Hancock, 1985; Farris et al., 1993; Fernandes et al., 1998). For example, initial studies performed with SCGs showed that axotomy results in decreased AChE activity (Klingman and Klingman, 1969; Viana and Kauffman, 1984). In addition, axotomy of the facial motor nuclei causes a rapid reduction of neuronal AChE activity and transcript levels (Tetzlaff and Kreutzberg, 1984; Fernandes et al., 1998). Importantly, Fernandes et al. (1998) also demonstrated that exogenous application of the target-derived trophic factors BDNF and NT4/5 prevented the decline in AChE mRNA levels (Fernandes et al., 1998). To date however, the mechanisms by which this rescue is mediated remain unknown. Given our current findings and the fact that many cellular and molecular effects of SCG axotomy result from loss of NGF (Klingman and Klingman, 1969; Federoff et al., 1992; Schober et al., 1997), it is tempting to speculate that there is a direct link between axotomy, levels of neurotrophic factors, HuD expression, and, ultimately, regulation of key transcripts in vivo including AChE and GAP-43.

Recent studies have also begun to address a putative role for $\mathrm{HuD}$ in regeneration of motoneurons and sensory neurons after axotomy (Anderson and Steward, 2003; Anderson et al., 2003). During the regenerative phase, these authors observed elevated levels of $\mathrm{HuD}$ and colocalization with ribonucleoprotein granules and GAP-43. Here, we observed decreased GAP-43 and HuD transcript levels early in the response to axotomy of SCG neurons (Fig. 7). In addition, exogenous expression of human $\mathrm{HuD}$, which compensated for the decrease in endogenous $\mathrm{HuD}$, rescued the expression of GAP-43 transcripts. HuD, therefore, because of its mRNA stabilizing activity of key transcripts involved in neurite outgrowth, is considered to be essential to the regeneration of peripheral neurons. Consequently, it is becoming apparent that a better understanding of the mechanisms regulating expression, activity, and function of $\mathrm{HuD}$ will increase our knowledge of the molecular events taking place during neuronal differentiation, growth, and plasticity. Moreover, this knowledge will be useful in designing novel therapies aimed at modulating $\mathrm{HuD}$ levels for treating neurodegenerative disorders or promoting nerve regeneration.

\section{References}

Akamatsu W, Fujihara H, Mitsuhashi T, Yano M, Shibata S, Hayakawa Y, Okano HJ, Sakakibara S, Takano H, Takano T, Takahashi T, Noda T, Okano H (2005) The RNA-binding protein HuD regulates neuronal cell identity and maturation. Proc Natl Acad Sci USA 102:4625-4630.

Alterio J, Mallet J, Biguet NF (2001) Multiple complexes involved in tyrosine hydroxylase mRNA stability in rat adrenal medulla, after reserpine stimulation. Mol Cell Neurosci 17:179-189.

Anderson KD, Steward O (2003) In vivo expression of the neuronal-specific RNA-binding protein $\mathrm{HuD}$ in reference to a potential target mRNA (GAP-43) in the mouse facial nucleus during regeneration. Soc Neurosci Abstr 29:78.17

Anderson KD, Sengupta J, Morin M, Neve RL, Valenzuela CF, PerroneBizzozero NI (2001) Overexpression of $\mathrm{HuD}$ accelerates neurite outgrowth and increases GAP-43 mRNA expression in cortical neurons and retinoic acid-induced embryonic stem cells in vitro. Exp Neurol 168:250-258.

Anderson KD, Merhege MA, Morin M, Bolognani F, Perrone-Bizzozero NI (2003) Increased expression and localization of the RNA-binding protein $\mathrm{HuD}$ and GAP-43 mRNA to cytoplasmic granules in DRG neurons during nerve regeneration. Exp Neurol 183:100-108.

Angus LM, Chan RY, Jasmin BJ (2001) Role of intronic E- and N-box motifs in the transcriptional induction of the acetylcholinesterase gene during myogenic differentiation. J Biol Chem 276:17603-17609.

Antic D, Lu N, Keene JD (1999) ELAV tumor antigen, Hel-N1, increases translation of neurofilament M mRNA and induces formation of neurites in human teratocarcinoma cells. Genes Dev 13:449-461.

Aranda-Abreu GE, Behar L, Chung S, Furneaux H, Ginzburg I (1999) Embryonic lethal abnormal vision-like RNA-binding proteins regulate neu- 
rite outgrowth and tau expression in PC12 cells. J Neurosci 19:6907-6917.

Bakheet T, Williams BR, Khabar KS (2006) ARED 3.0: the large and diverse AU-rich transcriptome. Nucleic Acids Res 34:D111-D114.

Barreau C, Paillard L, Osborne HB (2005) AU-rich elements and associated factors: are there unifying principles? Nucleic Acids Res 33:7138-7150.

Beckel-Mitchener AC, Miera A, Keller R, Perrone-Bizzozero NI (2002) Poly(A) tail length-dependent stabilization of GAP-43 mRNA by the RNA-binding protein HuD. J Biol Chem 277:27996-28002.

Bernard V, Legay C, Massoulie J, Bloch B (1995) Anatomical analysis of the neurons expressing the acetylcholinesterase gene in the rat brain, with special reference to the striatum. Neuroscience 64:995-1005.

Bolognani F, Merhege MA, Twiss J, Perrone-Bizzozero NI (2004) Dendritic localization of the RNA-binding protein $\mathrm{HuD}$ in hippocampal neurons: association with polysomes and upregulation during contextual learning. Neurosci Lett 371:152-157.

Bolognani F, Tanner DC, Merhege M, Deschênes-Furry J, Jasmin B, PerroneBizzozero NI (2006) In vivo post-transcriptional regulation of GAP-43 mRNA by overexpression of the RNA-binding protein HuD. J Neurochem 96:790-801.

Boudreau-Lariviere C, Sveistrup H, Parry DJ, Jasmin BJ (1996) Ciliary neurotrophic factor: regulation of acetylcholinesterase in skeletal muscle and distribution of messenger RNA encoding its receptor in synaptic versus extrasynaptic compartments. Neuroscience 73:613-622.

Boudreau-Lariviere C, Chan RY, Wu J, Jasmin BJ (2000) Molecular mechanisms underlying the activity-linked alterations in acetylcholinesterase mRNAs in developing versus adult rat skeletal muscles. J Neurochem 74:2250-2258.

Brimijoin S, Hammond P (1996) Transient expression of acetylcholinesterase messenger RNA and enzyme activity in developing rat thalamus studied by quantitative histochemistry and in situ hybridization. Neuroscience 71:555-565.

Chan RY, Adatia FA, Krupa AM, Jasmin BJ (1998) Increased expression of acetylcholinesterase $\mathrm{T}$ and $\mathrm{R}$ transcripts during hematopoietic differentiation is accompanied by parallel elevations in the levels of their respective molecular forms. J Biol Chem 273:9727-9733.

Chen CY, Shyu AB (1995) AU-rich elements: characterization and importance in mRNA degradation. Trends Biochem Sci 20:465-470.

Chung S, Eckrich M, Perrone-Bizzozero N, Kohn DT, Furneaux H (1997) The Elav-like proteins bind to a conserved regulatory element in the 3'-untranslated region of GAP-43 mRNA. J Biol Chem 272:6593-6598.

Coleman BA, Taylor P (1996) Regulation of acetylcholinesterase expression during neuronal differentiation. J Biol Chem 271:4410-4416.

Cuadrado A, Navarro-Yubero C, Furneaux H, Munoz A (2003) Neuronal $\mathrm{HuD}$ gene encoding a mRNA stability regulator is transcriptionally repressed by thyroid hormone. J Neurochem 86:763-773.

Deschênes-Furry J, Belanger G, Perrone-Bizzozero N, Jasmin BJ (2003) Post-transcriptional regulation of Acetylcholinesterase mRNAs in nerve growth factor-treated PC12 cells by the RNA-binding protein HuD. J Biol Chem 278:5710-5717.

Deschênes-Furry J, Belanger G, Mwanjewe J, Lunde JA, Parks RJ, PerroneBizzozero N, Jasmin BJ (2005) The RNA-binding protein HuR binds to acetylcholinesterase transcripts and regulates their expression in differentiating skeletal muscle cells. J Biol Chem 280:25361-25368.

Deschênes-Furry J, Perrone-Bizzozero N, Jasmin BJ (2006) The RNAbinding protein $\mathrm{HuD}$ : a regulator of neuronal differentiation, maintenance and plasticity. BioEssays 28:822-833.

Erondu NE, Nwankwo J, Zhong Y, Boes M, Dake B, Bar RS (1999) Transcriptional and posttranscriptional regulation of insulin-like growth factor binding protein-3 by cyclic adenosine $3^{\prime}, 5^{\prime}$-monophosphate: messenger RNA stabilization is accompanied by decreased binding of a $42-\mathrm{kDa}$ protein to a uridine-rich domain in the $3^{\prime}$-untranslated region. Mol Endocrinol 13:495-504.

Farris TW, Woolf NJ, Oh JD, Butcher LL (1993) Reestablishment of laminar patterns of cortical acetylcholinesterase activity following axotomy of the medial cholinergic pathway in the adult rat. Exp Neurol 121:77-92.

Federoff HJ, Geschwind MD, Geller AI, Kessler JA (1992) Expression of nerve growth factor in vivo from a defective herpes simplex virus 1 vector prevents effects of axotomy on sympathetic ganglia. Proc Natl Acad Sci USA 89:1636-1640.

Fernandes KJ, Kobayashi NR, Jasmin BJ, Tetzlaff W (1998) Acetylcholinesterase gene expression in axotomized rat facial motoneurons is differen- tially regulated by neurotrophins: correlation with trkB and trkC mRNA levels and isoforms. J Neurosci 18:9936-9947.

Flumerfelt BA, Lewis PR (1975) Cholinesterase activity in the hypoglossal nucleus of the rat and the changes produced by axotomy: a light and electron microscopic study. J Anat 119:309-331.

Ford LP, Wilusz J (1999) An in vitro system using HeLa cytoplasmic extracts that reproduces regulated mRNA stability. Methods 17:21-27.

Forster E, Otten U, Frotscher M (1993) Developmental neurotrophin expression in slice cultures of rat hippocampus. Neurosci Lett 155:216-219.

Fuentes ME, Taylor P (1993) Control of acetylcholinesterase gene expression during myogenesis. Neuron 10:679-687.

Fujiwara T, Mori Y, Chu DL, Koyama Y, Miyata S, Tanaka H, Yachi K, Kubo T, Yoshikawa H, Tohyama M (2006) CARM1 regulates proliferation of PC12 cells by methylating HuD. Mol Cell Biol 26:2273-2285.

Greene LA, Rukenstein A (1981) Regulation of acetylcholinesterase activity by nerve growth factor. Role of transcription and dissociation from effects on proliferation and neurite outgrowth. J Biol Chem 256:6363-6367.

Grifman M, Galyam N, Seidman S, Soreq H (1998) Functional redundancy of acetylcholinesterase and neuroligin in mammalian neuritogenesis. Proc Natl Acad Sci USA 95:13935-13940.

Grubic Z, Zajc-Kreft K, Brank M, Mars T, Komel R, Miranda AF (1999) Control levels of acetylcholinesterase expression in the mammalian skeletal muscle. Chem Biol Interact 119- 120:309-319.

Guhaniyogi J, Brewer G (2001) Regulation of mRNA stability in mammalian cells. Gene 265:11-23.

Hammond P, Rao R, Koenigsberger C, Brimijoin S (1994) Regional variation in expression of acetylcholinesterase mRNA in adult rat brain analyzed by in situ hybridization. Proc Natl Acad Sci USA 91:10933-10937.

Hew Y, Lau C, Grzelczak Z, Keeley FW (2000) Identification of a GA-rich sequence as a protein-binding site in the $3^{\prime}$-untranslated region of chicken elastin mRNA with a potential role in the developmental regulation of elastin mRNA stability. J Biol Chem 275:24857-24864.

Hoover DB, Hancock JC (1985) Effect of facial nerve transection on acetylcholinesterase, choline acetyltransferase and $[3 \mathrm{H}]$ quinuclidinyl benzilate binding in rat facial nuclei. Neuroscience 15:481-487.

Hosli E, Hosli L (1970) The presence of acetylcholinesterase in cultures of cerebellum and brain stem. Brain Res 19:494-496.

Jasmin BJ, Lee RK, Rotundo RL (1993) Compartmentalization of acetylcholinesterase mRNA and enzyme at the vertebrate neuromuscular junction. Neuron 11:467-477.

Jiang JX, Choi RC, Siow NL, Lee HH, Wan DC, Tsim KW (2003) Muscle induces neuronal expression of acetylcholinesterase in neuron-muscle co-culture: transcriptional regulation mediated by cAMP-dependent signaling. J Biol Chem 278:45435-45444.

Karpel R, Aziz-Aloya R, Sternfeld M, Ehrlich G, Ginzberg D, Tarroni P, Clementi F, Zakut H, Soreq H (1994) Expression of three alternative acetylcholinesterase messenger RNAs in human tumor cell lines of different tissue origins. Exp Cell Res 210:268-277.

Kasashima K, Terashima K, Yamamoto K, Sakashita E, Sakamoto H (1999) Cytoplasmic localization is required for the mammalian ELAV-like protein $\mathrm{HuD}$ to induce neuronal differentiation. Genes Cells 4:667-683.

Kasashima K, Sakashita E, Saito K, Sakamoto H (2002) Complex formation of the neuron-specific ELAV-like Hu RNA-binding proteins. Nucleic Acids Res 30:4519-4526.

Kaufer D, Friedman A, Seidman S, Soreq H (1998) Acute stress facilitates long-lasting changes in cholinergic gene expression. Nature 393:373-377.

Keene JD, Tenenbaum SA (2002) Eukaryotic mRNPs may represent posttranscriptional operons. Mol Cell 9:1161-1167.

Klimaschewski L, Tran TD, Nobiling R, Heym C (1994) Plasticity of postganglionic sympathetic neurons in the rat superior cervical ganglion after axotomy. Microsc Res Tech 29:120-130.

Klimaschewski L, Kummer W, Heym C (1996) Localization, regulation and functions of neurotransmitters and neuromodulators in cervical sympathetic ganglia. Microsc Res Tech 35:44-68.

Klingman GI, Klingman JD (1969) Cholinesterases of rat sympathetic ganglia after immunosympathectomy, decentralization and axotomy. J Neurochem 16:261-268.

Koelle GB (1954) The histochemical localization of cholinesterases in the central nervous system of the rat. J Comp Neurol 100:211-235.

Koenigsberger C, Chiappa S, Brimijoin S (1997) Neurite differentiation is modulated in neuroblastoma cells engineered for altered acetylcholinesterase expression. J Neurochem 69:1389-1397. 
Kohn DT, Tsai KC, Cansino VV, Neve RL, Perrone-Bizzozero NI (1996) Role of highly conserved pyrimidine-rich sequences in the $3^{\prime}$ untranslated region of the GAP-43 mRNA in mRNA stability and RNA-protein interactions. Brain Res Mol Brain Res 36:240-250.

Legay C (2000) Why so many forms of acetylcholinesterase? Microsc Res Tech 49:56-72.

Legay C, Bon S, Vernier P, Coussen F, Massoulie J (1993) Cloning and expression of a rat acetylcholinesterase subunit: generation of multiple molecular forms and complementarity with a Torpedo collagenic subunit. J Neurochem 60:337-346.

Lev-Lehman E, Deutsch V, Eldor A, Soreq H (1997) Immature human megakaryocytes produce nuclear-associated acetylcholinesterase. Blood 89:3644-3653.

Lev-Lehman E, Evron T, Broide RS, Meshorer E, Ariel I, Seidman S, Soreq H (2000) Synaptogenesis and myopathy under acetylcholinesterase overexpression. J Mol Neurosci 14:93-105.

Lopez de Silanes I, Zhan M, Lal A, Yang X, Gorospe M (2004) Identification of a target RNA motif for RNA-binding protein HuR. Proc Natl Acad Sci USA 101:2987-2992.

Luo Z, Fuentes ME, Taylor P (1994) Regulation of acetylcholinesterase mRNA stability by calcium during differentiation from myoblasts to myotubes. J Biol Chem 269:27216-27223.

Luo ZD, Wang Y, Werlen G, Camp S, Chien KR, Taylor P (1999) Calcineurin enhances acetylcholinesterase mRNA stability during C2-C12 muscle cell differentiation. Mol Pharmacol 56:886-894.

Ma WJ, Chung S, Furneaux H (1997) The Elav-like proteins bind to AU-rich elements and to the poly(A) tail of mRNA. Nucleic Acids Res 25:3564-3569.

Marusich MF, Furneaux HM, Henion PD, Weston JA (1994) Hu neuronal proteins are expressed in proliferating neurogenic cells. J Neurobiol 25:143-155.

Massoulie J, Pezzementi L, Bon S, Krejci E, Vallette FM (1993) Molecular and cellular biology of cholinesterases. Prog Neurobiol 41:31-91.

Meshorer E, Erb C, Gazit R, Pavlovsky L, Kaufer D, Friedman A, Glick D, Ben Arie N, Soreq H (2002) Alternative splicing and neuritic mRNA translocation under long-term neuronal hypersensitivity. Science 295:508-512.

Meshorer E, Toiber D, Zurel D, Sahly I, Dori A, Cagnano E, Schreiber L, Grisaru D, Tronche F, Soreq H (2004) Combinatorial complexity of 5' alternative acetylcholinesterase transcripts and protein products. J Biol Chem 279:29740-29751.

Mesulam MM, Geula C (1991) Acetylcholinesterase-rich neurons of the human cerebral cortex: cytoarchitectonic and ontogenetic patterns of distribution. J Comp Neurol 306:193-220.

Michel RN, Vu CQ, Tetzlaff W, Jasmin BJ (1994) Neural regulation of acetylcholinesterase mRNAs at mammalian neuromuscular synapses. J Cell Biol 127:1061-1069.

Mobarak CD, Anderson KD, Morin M, Beckel-Mitchener A, Rogers SL, Furneaux H, King P, Perrone-Bizzozero NI (2000) The RNA-binding protein $\mathrm{HuD}$ is required for GAP-43 mRNA stability, GAP-43 gene expression, and PKC-dependent neurite outgrowth in PC12 cells. Mol Biol Cell 11:3191-3203.

Neve RL, Howe JR, Hong S, Kalb RG (1997) Introduction of the glutamate receptor subunit 1 into motor neurons in vitro and in vivo using a recombinant herpes simplex virus. Neuroscience 79:435-447.

Okano HJ, Darnell RB (1997) A hierarchy of Hu RNA binding proteins in developing and adult neurons. J Neurosci 17:3024-3037.

Park-Lee S, Kim S, Laird-Offringa IA (2003) Characterization of the interaction between neuronal RNA-binding protein $\mathrm{HuD}$ and AU-rich RNA. J Biol Chem 278:39801-39808.

Pascale A, Gusev PA, Amadio M, Dottorini T, Govoni S, Alkon DL, Quattrone A (2004) Increase of the RNA-binding protein $\mathrm{HuD}$ and posttranscriptional up-regulation of the GAP-43 gene during spatial memory. Proc Natl Acad Sci USA 101:1217-1222.

Pascale A, Amadio M, Scapagnini G, Lanni C, Racchi M, Provenzani A, Govoni S, Alkon DL, Quattrone A (2005) Neuronal ELAV proteins enhance mRNA stability by a PKCalpha-dependent pathway. Proc Natl Acad Sci USA 102:12065-12070.

Perrone-Bizzozero N, Bolognani F (2002) Role of HuD and other RNAbinding proteins in neural development and plasticity. J Neurosci Res 68:121-126.

Perrone-Bizzozero NI, Neve RL, Irwin N, Lewis SE, Fischer I, Benowitz LI
(1991) Post-transcriptional regulation of GAP-43 mRNA levels during neuronal differentiation and nerve regeneration. Mol Cell Neurosci 2:402-409.

Perry C, Sklan EH, Birikh K, Shapira M, Trejo L, Eldor A, Soreq H (2002) Complex regulation of acetylcholinesterase gene expression in human brain tumors. Oncogene 21:8428-8441.

Quattrone A, Pascale A, Nogues X, Zhao W, Gusev P, Pacini A, Alkon DL (2001) Posttranscriptional regulation of gene expression in learning by the neuronal ELAV-like mRNA-stabilizing proteins. Proc Natl Acad Sci USA 98:11668-11673.

Rotundo RL (2003) Expression and localization of acetylcholinesterase at the neuromuscular junction. J Neurocytol 32:743-766.

Sagesser R, Martinez E, Tsagris M, Tabler M (1997) Detection and isolation of RNA-binding proteins by RNA-ligand screening of a cDNA expression library. Nucleic Acids Res 25:3816-3822.

Schober A, Minichiello L, Keller M, Huber K, Layer PG, Roig-Lopez JL, Garcia-Arraras JE, Klein R, Unsicker K (1997) Reduced acetylcholinesterase (AChE) activity in adrenal medulla and loss of sympathetic preganglionic neurons in TrkA-deficient but not TrkB-deficient mice. J Neurosci 17:891-903.

Seidman S, Sternfeld M, Aziz-Aloya R, Timberg R, Kaufer-Nachum D, Soreq H (1995) Synaptic and epidermal accumulations of human acetylcholinesterase are encoded by alternative $3^{\prime}$-terminal exons. Mol Cell Biol 15:2993-3002.

Sharma KV, Koenigsberger C, Brimijoin S, Bigbee JW (2001) Direct evidence for an adhesive function in the noncholinergic role of acetylcholinesterase in neurite outgrowth. J Neurosci Res 63:165-175.

Siow NL, Choi RC, Cheng AW, Jiang JX, Wan DC, Zhu SQ, Tsim KW (2002) A cyclic AMP-dependent pathway regulates the expression of acetylcholinesterase during myogenic differentiation of $\mathrm{C} 2 \mathrm{C} 12$ cells. J Biol Chem 277:36129-36136.

Siow NL, Xie HQ, Choi RC, Tsim KW (2005) ATP induces the post-synaptic gene expression in neuron-neuron synapses: transcriptional regulation of AChE catalytic subunit. Chem Biol Interact 157-158:423-426.

Soreq H, Seidman S (2001) Acetylcholinesterase-new roles for an old actor. Nat Rev Neurosci 2:294-302.

Sternfeld M, Ming G, Song H, Sela K, Timberg R, Poo M, Soreq H (1998) Acetylcholinesterase enhances neurite growth and synapse development through alternative contributions of its hydrolytic capacity, core protein, and variable C termini. J Neurosci 18:1240-1249.

Sun Y, Zigmond RE (1996) Involvement of leukemia inhibitory factor in the increases in galanin and vasoactive intestinal peptide mRNA and the decreases in neuropeptide $\mathrm{Y}$ and tyrosine hydroxylase mRNA in sympathetic neurons after axotomy. J Neurochem 67:1751-1760.

Szabo A, Dalmau J, Manley G, Rosenfeld M, Wong E, Henson J, Posner JB, Furneaux HM (1991) HuD, a paraneoplastic encephalomyelitis antigen, contains RNA-binding domains and is homologous to Elav and Sexlethal. Cell 67:325-333.

Taxi J, Eugene D (1995) Effects of axotomy, deafferentation, and reinnervation on sympathetic ganglionic synapses: a comparative study. Int Rev Cytol 159:195-263.

Tenenbaum SA, Lager PJ, Carson CC, Keene JD (2002) Ribonomics: identifying mRNA subsets in mRNP complexes using antibodies to RNAbinding proteins and genomic arrays. Methods 26:191-198.

Tetzlaff W, Kreutzberg GW (1984) Enzyme changes in the rat facial nucleus following a conditioning lesion. Exp Neurol 85:547-564.

Viana GB, Kauffman FC (1984) Cholinesterase activity in the rat superior cervical ganglion: effect of denervation and axotomy. Brain Res 304:37-45.

Wan DC, Choi RC, Siow NL, Tsim KW (2000) The promoter of human acetylcholinesterase is activated by a cyclic adenosine $3^{\prime}, 5^{\prime}$ monophosphate-dependent pathway in cultured NG108-15 neuroblastoma cells. Neurosci Lett 288:81-85.

Wilson GM, Brewer G (1999) Identification and characterization of proteins binding A + U-rich elements. Methods 17:74-83.

Xu N, Chen CY, Shyu AB (1997) Modulation of the fate of cytoplasmic mRNA by AU-rich elements: key sequence features controlling mRNA deadenylation and decay. Mol Cell Biol 17:4611-4621.

Young C, Lindsay S, Vater R, Slater CR (1998) An improved method for the simultaneous demonstration of mRNA and esterase activity at the human neuromuscular junction. Histochem J 30:7-11. 